\title{
Exploring the terms used for the oldest old in the gerontological literature.
}

KYDD, A., FLEMING, A., PAOLETTI, I. and HVALIČ-TOUZERY, S. 
The Journal of

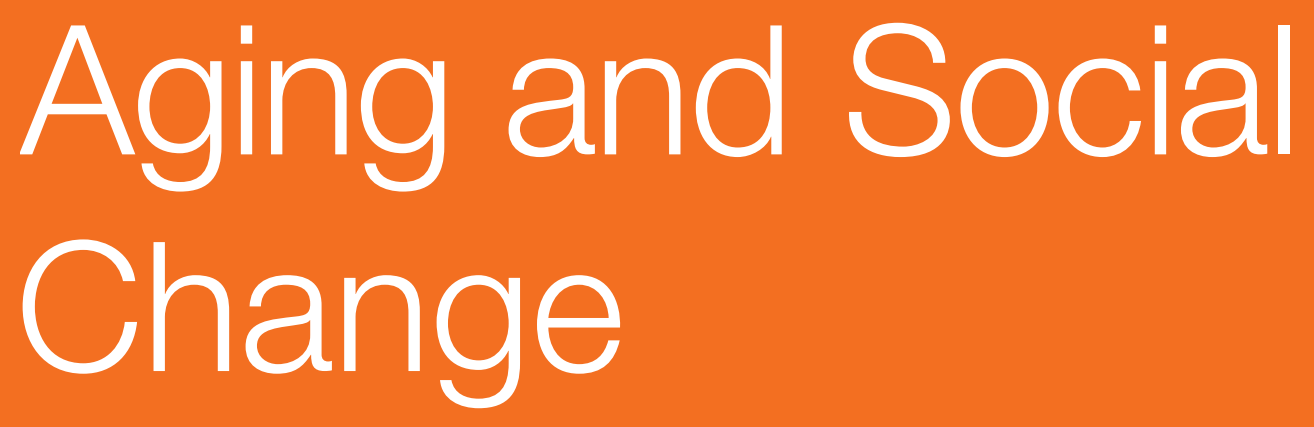

\section{Exploring Terms Used for the Oldest Old in the Gerontological Literature}




\section{EDITOR}

Andreas Motel-Klingebiel, Linkoping University, Sweden

ACTING DIRECTOR OF PUBLISHING

Jeremy Boehme, Common Ground Research Networks, USA

\section{MANAGING EDITOR}

Helen Repp, Common Ground Research Networks, USA

\section{ADVISORY BOARD}

The Aging and Social Change Research Network recognizes the contribution of many in the evolution of the Research Network. The principal role of the Advisory Board has been, and is, to drive the overall intellectual direction of the Research Network. A full list of members can be found at https://agingandsociety.com/about/advisoryboard.

\section{PEER REVIEW}

Articles published in The Journal of Aging and Social Change are peer reviewed using a two-way anonymous peer review model. Reviewers are active participants of the Aging and Social Change Research Network or a thematically related Research Network. The publisher, editors, reviewers, and authors all agree upon the following standards of expected ethical behavior, which are based on the Committee on Publication Ethics (COPE) Core Practices. More information can be found at: https://agingandsociety.com/journal/model.

\section{ARTICLE SUBMISSION}

The Journal of Aging and Social Change publishes quarterly (March, June, September, December). To find out more about the submission process, please visit

THE JOURNAL OF AGING AND SOCIAL CHANGE https://agingandsocialchange.com ISSN 2576-5310 (Print)

ISSN 2576-5329 (Online)

https://doi.org/10.18848/2576-5310/CGP (Journal)

First published by Common Ground Research Networks in 2020 University of Illinois Research Park

2001 South First Street, Suite 202

Champaign, IL 61820 USA

$\mathrm{Ph}:+1-217-328-0405$

https://cgnetworks.org

The Journal of Aging and Social Change

is a peer-reviewed, scholarly journal.

\section{COPYRIGHT}

(C) 2020 (individual papers), the author(s)

(C) 2020 (selection and editorial matter),

Common Ground Research Networks

All rights reserved. Apart from fair dealing for the purposes of study, research, criticism, or review, as permitted under the applicable copyright legislation, no part of this work may be reproduced by any process without written permission from the publisher. For permissions and other inquiries, please contact cgscholar.com/cg_support.

\section{Crossref}

Common Ground Research Networks, a member of Crossref https://agingandsociety.com/journal/call-for-articles.

\section{ABSTRACTING AND INDEXING}

For a full list of databases in which this journal is indexed, please visit https://agingandsociety.com/journal.

\section{RESEARCH NETWORK MEMBERSHIP}

Authors in The Journal of Aging and Social Change

are members of the Aging and Social Change Research Network or a thematically related Research Network. Members receive access to journal content. To find out more, visit

https://agingandsociety.com/about/become-a-member.

\section{SUBSCRIPTIONS}

The Journal of Aging and Social Change is available in electronic and print formats. Subscribe to gain access to content from the current year and the entire backlist. Contact us at cgscholar.com/cg_support.

\section{ORDERING}

Single articles and issues are available from the journal bookstore at https://cgscholar.com/bookstore.

\section{HYBRID OPEN ACCESS}

The Journal of Aging and Social Change is Hybrid Open Access, meaning authors can choose to make their articles open access. This allows their work to reach an even wider audience, broadening the dissemination of their research. To find out more, please visit https://agingandsociety.com/journal/hybrid-open-access.

\section{DISCLAIMER}

The authors, editors, and publisher will not accept any legal responsibility for any errors or omissions that may have been made in this publication. The publisher makes no warranty, express or implied, with respect to the material contained herein. 


\title{
Exploring Terms Used for the Oldest Old in the Gerontological Literature
}

\author{
Angela Kydd, ${ }^{1}$ Robert Gordon University, UK \\ Anne Fleming, Independent Researcher, UK \\ Isabella Paoletti, Social Research and Intervention Centre (CRIS), Italy \\ Simona Hvalič-Touzery, University of Ljubljana, Slovenia
}

\begin{abstract}
Background: In response to the global increasing age of the population, there is general agreement on the need to define what is meant by "old." Yet there is no consensus on age groups within the definition of old, which makes comparative studies of people of differing ages in advancing years impossible. Attempts to sub-categorize the "old" also show little consensus. This article serves to open a dialogue, as an illustrative example of these inconsistencies. Aim: To examine definitions of the "oldest old" and "fourth age" in order to highlight such inconsistencies and the need for consistent age stratifications. Method: The authors conducted a literature search from January 2003 to April 2015 using the six top-most-rated non-medical journals in gerontology and again in 2018-2019 to give currency to the article. Results: Forty-nine articles in total were reviewed. The findings show little consensus on the age stratifications used to define the "oldest old" and "fourth age," which ranged from seventy-five plus to ninety-two plus years. Conclusion: Dividing the "old" population into the oldest old and/or fourth age still shows a lack of consensus, with some authors suggesting that such divisions have only served to move ageism into very old age. Recommendation: There are terms for ten-year cohorts, which if universally used, will mean that comparative ageing studies are possible, which in turn will inform international and national strategy documents, policy initiatives, clinical guidelines, and service provision design. Implications for Practice: Given the growth in the numbers of people classed as old and the time span being "old" covers, there is a real need for consensus. Definite age groupings that define people as cohorts, with existing and agreed words - such as sexagenarians (60-69,) septuagenarians (70-79), octogenarians (80-89), etc., will completely remove the need for the value-laden term "old" (and all its derivatives) for this poorly defined population.
\end{abstract}

Keywords: Oldest-old, Fourth Age, 85+, 85 Plus, Age Stratification, Ageism

\section{Introduction}

T

This article aims to add to the dialogue on the term "old" by providing a pilot review, as an exemplar, to explore empirically how people aged over 80 years are termed and defined in a limited selection of the gerontological literature. It argues for the use of age cohorts in decades, which would serve to negate the use of such terms "old," "older people," "oldest old," and "fourth age," to name but a few. Such terms not only have ageist connotations, which will be addressed below, but give no consensus for academics, researchers, policy makers, and educators to work on. The lack of consensus is apparent in papers and policies regardless of discipline or country. Such inconsistencies make comparative research on the "old," and even sub-categories of the term old, impossible. This article gives reasons why cohort classifications (such as septuagenarians, octogenarians, etc.) will not only help to ameliorate the negative imagery that accompanies the scarcely meaningful term "oldest old" but serve to appreciate that research involving people needs to acknowledge the individual's cohort and the role their society ascribes to them at the age they are, along with their environment and culture. As Woods $(1996,4)$ states "the older person cannot be studied in isolation from their context: they are enmeshed in a presumptive world order, rich in accumulated expectancies."

There is some agreement in the literature that old age begins at the age of 60 or 65 , due in part to the age at which women and men retire from the workforce, so old age was commonly

\footnotetext{
${ }^{1}$ Corresponding Author: Angela Kydd, Robert Gordon University and NHS Grampian. School of Nursing and Midwifery, Garthdee Campus, Aberdeen, AB10 7QG, Scotland, UK. email: a.kydd@rgu.ac.uk
}

The Journal of Aging and Social Change

Volume 10, Issue 2, 2020, https://agingandsocialchange.com

(C) Common Ground Research Networks, Angela Kydd, Anne Fleming, Isabella Paoletti,

Simona Hvalič-Touzery, All Rights Reserved. Permissions: cgscholar.com/cg_support

ISSN: 2576-5310 (Print), ISSN: 2576-5329 (Online)

https://doi.org/10.18848/2576-5310/CGP/v10i02/53-73 (Article) 
determined with retirement as a measure. Yet globally, people are living many years longer following their retirement and, as a response to this, retirement ages are increasing and these ages differ between countries. Therefore, defining old age as starting at retirement is ever more problematic. Attempts to sub-categorize those classed as old into such terms as the "oldest old" and "fourth age" (terms usually ascribed to those aged 80+) again imply a shared understanding. However, the age bands used to define these terms vary greatly.

This article presents an exploratory discourse on the lack of consensus and shared understanding on the nature of the "oldest old" and the "fourth age" and suggests that people should be referred to by their age cohort. This study supports earlier work by Serra et al. (2011) who suggest that cohort age classifications would dispel the ageist imagery that comes with defining the "old." It also responds to the call by Sabharwal et al. (2015) who recommend that popular definitions of "old people" should be uniform and agreed. They point out that research on the "elderly" cover ages of 50 and over, usually broken into disparate age bands, thus making research clinically irrelevant on this population.

\section{Background}

The term "older people" is seen by many researchers as a crude and unhelpful categorization of mature and ageing people. In the 1970s, Neugarten (1974) put forward the concept that older people are not one homogeneous group and that age stratification would serve to delineate between the characteristics of the fit old and the needy old. She suggested the "young old" (55-75), those who were retired but healthy, affluent, and politically active, and the "old old" (over 75), those who might need supportive services to function as fully as possible. These age bands gave no consideration to factors that affect people as they age, such as culture, socioeconomic status, health status, or environment. Yet, they did serve to acknowledge that classifying people as old, from the age of 60 to potentially the age of 110 , was far too broad to have any meaning. Similarly, the concept of the "Third Age" and "Fourth Age" is associated with Laslett (1994), who sought to dispel marginalization of the old. Laslett (1994) argued that following retirement, the "old" were an active group of economic importance. This concept addressed the negative imagery (ageism) of the retired person but introduced the concept of the fourth age, where dependency represented a key marker in the transition from third to fourth age. The development of ideas about later life serve to emphasize autonomy, agency, and selfactualization but also serve to distinguish the concept of the fourth age, where dependency represents a key marker in the transition. Komp (2011) concurs with Laslett's work, that the fourth agers are distinct from "third agers." The third agers are healthy retirees who contribute to the economy, whilst the fourth agers are retirees in poor health-those who fit the stereotype of "old people." Again, this is not particularly helpful for ageing studies because age alone does not determine health status or economic contribution. In essence, dividing groups by economic contribution has served to move ageism into very old age, in that old people are viewed as unproductive and a drain on health and social care resources. Arguments against such categories of old have been put forward by George (2011), who suggests that in creating a third and fourth age division, a more severe form of ageism is created for those in the fourth age. She states, "just as the image of the Third Age is socially desirable because it is not old age, the image of a Fourth Age is socially undesirable because it reinforces negative stereotypes of later life. Fourth Agers will be viewed as frail, dependent, lonely, sick and as coping with impending death" (George 2011, 253). This sentiment is backed by Gilleard and Higgs (2015), who describe the fourth age as absorbing all the negative aspects of the aging process by exaggerating a gap between the fit and the frail, creating a fear for those who see themselves as transitioning from their third to fourth age (Kydd et al. 2018). This supports earlier work by Kleinspehn-Ammerlahn (2008), who used longitudinal data from the Berlin Ageing Study over six years and found that people generally felt around thirteen years younger than their chronological age until they experienced illness or social loneliness due to the illness(es) or the loss of a significant other. Such losses lead 
individuals to perceive themselves to be old as per Neugarten's (1974) stages or Laslett's (1994) fourth age.

North and Fiske (2013) criticize ageism research for considering the over $65 \mathrm{~s}$ as a homogeneous group. They recommend that ageism studies should focus on the subgroupings of "young-old" and "old-old" as described by Neugarten (1974). This, they state, would lead to a better understanding of the unique prejudices encountered by sub-categories. They further state that grouping everyone over a certain age as old is an antiquated definition that will become even more so with anticipated increasing longevity.

These discourses make important distinctions but do little to provide consensus on what is meant by the terms "older people," "oldest old," and "fourth age." Yet age stratifications have been adopted in policy documents and today, the vast majority of ageing studies and policy documents use age bands to define an "old" population (Baars 2007). Yet again, there is no uniformity to the age stratifications used and this can be seen in five such examples: WHO (2015) report on the over 60s, 70s, and 80s as does Age International (2015) and Eurostat (Eurostat 2019a), while the United Nations (2015) indicate the old (over 65) and the oldest old (over 85), and the Association of Directors of Public Health (2018) refer to people aged 65-74 and the over 75-year-olds. Thus the literature and policy documents on "older people," "later life," and "oldest-old" use different age stratifications and terminologies, which makes such classifications meaningless (Cohen-Mansfield et al. 2013).

In Japan, there have been moves to reach a national agreement on what constitutes old and oldest old. The rationale for redefining the term "elderly" in Japan was the growing numbers of people younger than 75 who were robust and active. A cross sectional study on the physical and psychological health of older people in Japan found a phenomenon of "rejuvenation," where the traits of ageing were found to have been delayed by five to ten years. This Japanese study informed the work of the Japan Gerontological Society and the Japan Geriatrics Society to reconsider the definition of older people (Ouchi et al. 2017). After three years' work, the committee proposed the following classification: 65 to 74 years (pre-old age), 75 and over (old age), and 90 and over (oldest-old or super-old). The authors conclude that the two main aims of redefining "elderly" were to motivate those aged 60-74 to continue to be active and valued contributors to society and to create a super-aged population in a positive way. This approach to categories will be useful for ageing studies, but still comes with an implicit trajectory of becoming disabled. Follow-up work will be interesting to see if those who transition from the old age category will view themselves in a positive way when classed as the oldest old/ super old at 90 .

Chronological age is a fact but the effects of ageing are diverse and unique. In gaining consensus as to who "older people" are, it appears that the problem lies between the concepts of biological age and chronological age. Baars (2010) refers to three dimensions of ageing: (1) natural (physical and biological), (2) socio-cultural, and (3) personal. This acknowledges that ageing is not a regular process. Chronological age does not predict bodily decline. Moreover, as Baars $(2010,10)$ points out "all human aging takes place in specific contexts which co-constitute its outcomes," which means that by having an agreement on using cohort age bands it will then be possible to compare and contrast how different cohorts age, with consideration to the dimensions of ageing.

Agreement has to be reached. The growing numbers of people aged over 60 and the booming numbers of people aged over 80 illustrate that age cohorts need to be considered as acceptable ways in which to refer to "older people." According to Eurostat data (Eurostat 2019a), 28.6 million people aged 80 and over were living in the European Union (EU-28) in 2018, 6.6 million more than ten years ago. The growing share of older people in the EU-28 (from $4.4 \%$ in 2008 to $5.6 \%$ in 2018 ) illustrates that in 2018 , one in every eighteen people living in the EU were aged 80 and over. This increase was seen in all Member States, except Sweden (Eurostat 2019b). 
These numbers, although important in terms of understanding demographic trends, do not reflect the heterogeneity of the older population. It is widely understood that differences among people of the same age may be greater than those attributed to chronological age differences. A growing body of research indicates that a person's ageing is influenced by multiple factors such as genetics, socioeconomic factors, and environmental factors (Lowsky et al. 2014; Mitnitski, Howlett, and Rockwood 2017; Yashin et al. 2016; Andrew 2015). People in specific age cohorts aged $60,70,80,90,100$, and 110 all share a historical context and sub groups within these cohorts will share certain commonalities such as socioeconomic status and cultural status within that context. Thus, referring to sexagenarians (60-69) and septuagenarians (70-79), and so on, provides a common understanding of who are actually being researched.

A study on the use of the term "older people" (and if possible, the definitive ages ascribed) would be too large to undertake for an unfunded pilot study. Studies discussing (as opposed to using) the definitions of the terms "oldest old" and "fourth age" are relatively scarce (Gilleard and Higgs 2013, 2015). So the authors undertook a pilot study to empirically review how the terms "oldest old" and "fourth age" are articulated in the relevant gerontological literature; thus the articles were used as data. The aim is to illustrate the uselessness of the term "older people" and the lack of consensus in determining the contemporary differing terms used for the "oldest old" and "fourth age."

\section{Method}

The methodological approach of this study is not a conceptual analysis of the term "oldest old"; the authors' approach is empirical and serves as a pilot study. This study examines the language use of the terms "fourth age" and "oldest old" in a specific scientific community-researchers in gerontology. Gerontological articles were used as data and a sociolinguistic approach was adopted (Wodak, Johnstone, and Kerswill 2011). This pilot study examined the use of the terms "fourth age" and "oldest old" (which will yield corresponding terms) in relation to age grouping, in six top-rated journals in gerontology (Guerrero-Bote and Moya-Anegón 2012). These journals, with their impact factors from 2015 are: Age and Aging (4.282), The Gerontologist (3.505), The Journals of Gerontology B (3.064), Aging \& Mental Health (2.658), Ageing \& Society (1.386), Research on Ageing (1.214). Whilst aware that there are many other journals in gerontology and many articles on old age that are included in non-gerontological specific journals, the decision was made that these journals represented an appropriate starting point for inquiry, being the most read and most quoted journals among researchers in the field of gerontology. The six journals were accessed on line and examined from years 2003 to 2015. There were no specific reasons for choosing this particular time span; a different one could have been chosen to test language use for this pilot study; it is a significantly long period of time (thirteen years) but manageable within the scope of an initial research. The rationale for the search was to highlight how the term old is poorly defined and yet used to describe and cater for populations as if a shared understanding exists. The search terms used were to seek consensus of subcategories of old, namely the "oldest old" and "fourth age."

In order to provide currency to this article, which took several years to complete, a second recent search was conducted. To provide consistency, the same journals and search terms were used. However, the time limit specified was for the period January 2018 to March 2019.

\section{Keywords and Inclusion Criteria}

The authors' search strategy involved accessing the chosen journals' websites, and inserting the keywords "fourth age" and "oldest old" in the searching quadrant. All terms were searched as phrases within quotation marks to avoid meaningless returns. The inclusion criteria for the original search were articles published between 2003 and 2015, full text articles, and written in English. The follow-up search (January 2018 to March 2019) involved the same strategy. The 
exclusion criteria evolved as the screening procedure developed. Justification for this is documented throughout the three levels of screening detailed below.

\section{Screening Procedure (1)}

The 2003-2015 search using the keywords yielded the following results: Age and Ageing 131; Ageing \& Mental Health 61; Aging \& Society 56; Research on Aging 73; The Gerontologist 117; The Journals of Gerontology 163; giving a total of 601 articles (see Figure 1 for a breakdown of the screening process and findings). The 2018-2019 yielded fifty-one articles (see Figure 2): Age and Ageing 3; Ageing and Mental Health 7; Aging \& Society 9; Research on Aging 6; The Gerontologist 3; The Journals of Gerontology 23.

Prior to independent screening by the authors, exclusion criteria were developed to refine the search results to provide a greater focus on the use of the terms "fourth age" and "oldest old." These were topics related to specific health conditions; older people undergoing treatment for a clinically diagnosed physical illness (e.g., cancer) or mental illness (e.g., dementia or depression); assessments for long-term continuing care; community interventions to improve the physical and social environment that are not directly targeted at people over 65 or their carers; interventions tailored to those in acute or palliative care; medical or surgical interventions; preretirement financial planning schemes; specific therapeutic interventions for diagnosed mental health disorders covered by National Institute for Clinical Excellence (NICE) guidelines, such as reminiscence therapy and cognitive behavioral therapy. The results were then discussed and agreed, which resulted in the rejection of 266 articles in the first part of this study (2003-2015) and thirty rejections for the updated part (2018-2019).

\section{Screening Procedure (2)}

Further exclusion criteria were developed as the authors became familiar with the literature, and these were then used for a joint second screening. This included articles that gave no useful age stratification when discussing old and oldest old studies; articles that compared "younger," "middle aged," and "older" people; articles that used a mean age; articles that used purely over age 50; articles that gave no rationale for an unusual age bracket; articles referring solely to "older adults." Following this second screening, a further 102 papers were rejected from the 2003-2015 search, leaving 233 papers for review; and in the 2018-2019 search, twelve were rejected leaving nine papers for review.

\section{Screening Procedure (3)}

Due to the volume of papers, a third screening was undertaken to narrow the focus further. With the aims of the article in mind, the authors decided to acknowledge but exclude the many longitudinal studies that segregated the ages of the old, but did not add to the discourse surrounding the divisions between the third and fourth ages, or old and oldest old. Longitudinal studies can use any age parameters selected from the datasets. However, because these studies selected participants aged 80, 85, 90, and 100 (illustrating the lack of consensus on the "oldest old"), the authors agreed to reject these. Such studies included Leiden 85-plus Study (Caljouw et al. 2013), The OCTO-Twin Study (Hassing et al. 2004), and The Georgia Centenarian Study (Cho et al. 2015). Further exclusions were studies that focused on single issues that did not add to the discourse on the fourth age and the oldest old. Therefore, the third screening had the following exclusion criteria: longitudinal studies; veteran studies; and, studies focused on dementia and depression. This resulted in 185 papers being excluded and a manageable fortyeight retained for examination (see Figure 1). 


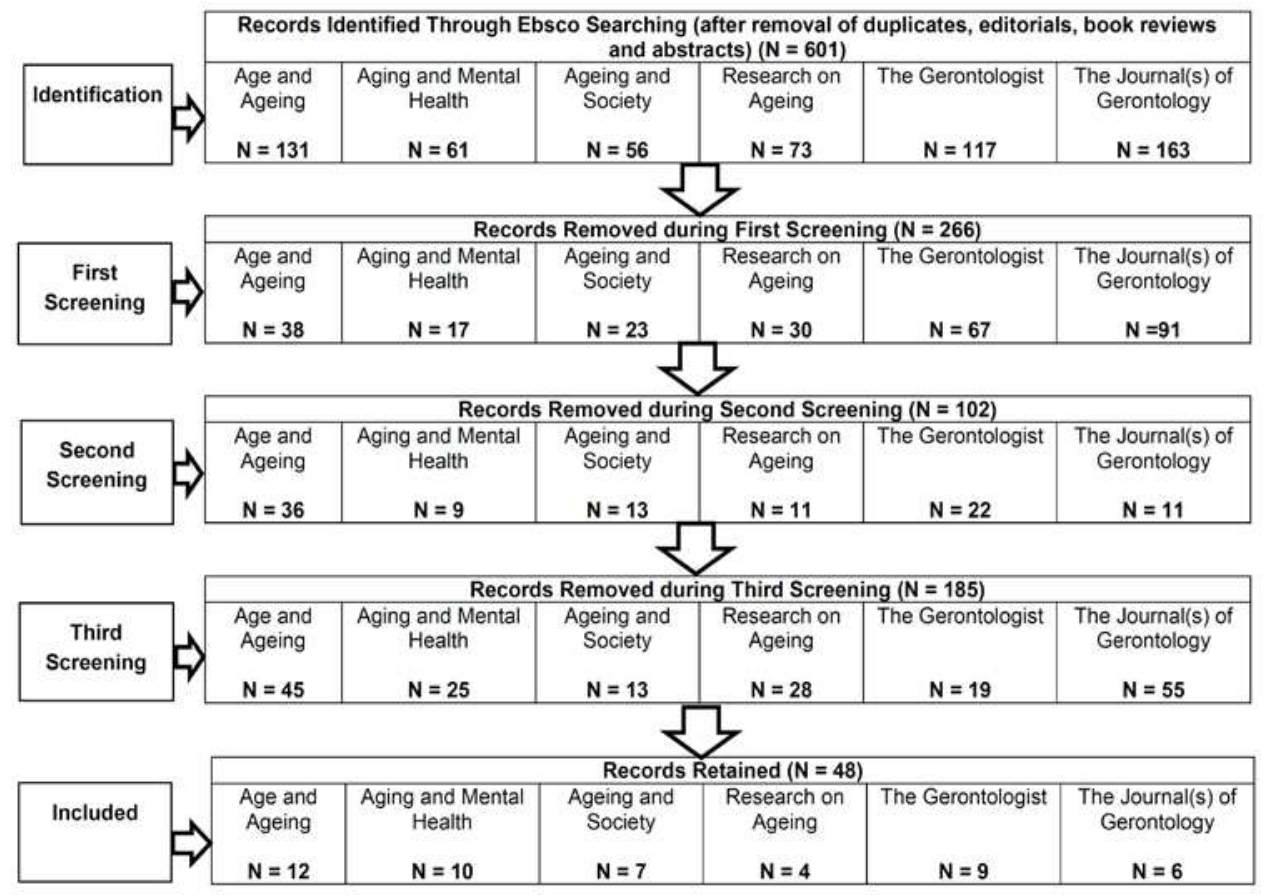

Figure 1: Flow Diagram of Article Selection 2003-2015

Source: Kydd et al. 2020

Out of the selected forty-eight studies, nine were observational studies, twenty-four quantitative, five qualitative studies, four register-based studies, two expert opinions, one mixedmethods, one a systematic review of the cohort studies, one experimental, and one ethnographic study. Half $(\mathrm{n}=24)$ of the studies were conducted in European countries and eighteen in North America. The remaining studies were carried out in Asia $(n=4)$ and Malaysia $(n=1)$. Six studies were conducted in partnership between countries in different regions (see Table 1).

Table 1: Characteristics of the Reviewed Articles

\begin{tabular}{|l|l|l|l|l|l|}
\hline No & \multicolumn{1}{|c|}{ Author/Year } & \multicolumn{1}{|c|}{ Study Type } & \multicolumn{1}{|c|}{$N$} & $\begin{array}{l}\text { Age in } \\
\text { Sample }\end{array}$ & \multicolumn{1}{|c|}{ Country. Discipline } \\
\hline 1. & $\begin{array}{l}\text { Beel-Bates, Ingersoll- } \\
\text { Dayton, and Nelson 2007 }\end{array}$ & Qualitative & 31 & $85+$ & USA. Social Work \\
\hline 2. & Berg et al. 2006 & Quantitative & 315 & $80-98$ & $\begin{array}{l}\text { Sweden/ USA. } \\
\text { Psychology }\end{array}$ \\
\hline 3. & Birditt 2014 & Quantitative & 110 & $40-95$ & USA. Psychology \\
\hline 4. & Birditt and Fingerman 2003 & Quantitative & 185 & $13-99$ & USA. Psychology \\
\hline 5. & Bowling and Grundy 2009 & $\begin{array}{l}\text { Observational - } \\
\text { Cross-sectional }\end{array}$ & 1.384 & $85+$ & $\begin{array}{l}\text { United Kingdom. } \\
\text { Social Science }\end{array}$ \\
\hline 6. & Bowling et al 2005 & Quantitative & 533 & $65+$ & $\begin{array}{l}\text { United Kingdom. } \\
\text { Social Science }\end{array}$ \\
\hline 7. & Boyes 2013 & Mixed methods & 80 & $\begin{array}{l}63-80 / \\
54-83\end{array}$ & $\begin{array}{l}\text { New Zealand. } \\
\text { Education }\end{array}$ \\
\hline 8. & Braungart et al. 2007 & $\begin{array}{l}\text { Observational } \\
\text { cohort }\end{array}$ & 149 & $\begin{array}{l}86,90, \\
84\end{array}$ & $\begin{array}{l}\text { USA/ Sweden. } \\
\text { Psychology }\end{array}$ \\
\hline 9. & $\begin{array}{l}\text { Bronnum-Hansen et al. } \\
2009\end{array}$ & $\begin{array}{l}\text { Observational } \\
\text { cohort }\end{array}$ & 2.258 & $92-100$ & $\begin{array}{l}\text { Denmark. } \\
\text { Public Health }\end{array}$ \\
\hline 10. & Chipperfield 2008 & Quantitative & 198 & $80-98$ & $\begin{array}{l}\text { USA/Canada } \\
\text { Psychology }\end{array}$ \\
\hline
\end{tabular}


KYDD ET AL.: EXPLORING TERMS USED FOR THE OLDEST OLD

\begin{tabular}{|c|c|c|c|c|c|}
\hline 11. & Cicirelli 2006 & Quantitative & 192 & $60-84$ & USA. Psychology \\
\hline 12. & Conroy et al. 2014 & $\begin{array}{l}\text { Observational } \\
\text { cohort }\end{array}$ & 7.5 & $85+$ & $\begin{array}{l}\text { United Kingdom. } \\
\text { Medicine }\end{array}$ \\
\hline 13. & Cotter et al 2009 & $\begin{array}{l}\text { Observational } \\
\text { cohort }\end{array}$ & 250 & $65+$ & $\begin{array}{l}\text { Ireland. } \\
\text { Medicine }\end{array}$ \\
\hline 14. & Duncan 2008 & Opinion & & & $\begin{array}{l}\text { United Kingdom. } \\
\text { Medicine }\end{array}$ \\
\hline 15. & $\begin{array}{l}\text { Engelter, Bonati, and Lyrer } \\
2006\end{array}$ & $\begin{array}{l}\text { Systematic } \\
\text { review of cohort } \\
\text { studies }\end{array}$ & $\begin{array}{l}6 \text { studies } \\
(n=2,244)\end{array}$ & $80+$ & $\begin{array}{l}\text { Switzerland. } \\
\text { Medicine }\end{array}$ \\
\hline 16. & Erlangsen et al 2004 & Register-based & 2.505 & $50+$ & $\begin{array}{l}\text { Germany/Denmark. } \\
\text { Sociology }\end{array}$ \\
\hline 17. & Fastame et al. 2013 & Quantitative & 96 & $85+$ & $\begin{array}{l}\text { Italy. } \\
\text { Psychology }\end{array}$ \\
\hline 18. & Fastamea and Penna 2014 & Quantitative & 94 & $75-99$ & $\begin{array}{l}\text { Italy. } \\
\text { Psychology }\end{array}$ \\
\hline 19. & Gott et al 2006 & Quantitative & 542 & $60+$ & $\begin{array}{l}\text { United Kingdom. } \\
\text { Nursing }\end{array}$ \\
\hline 20. & Gunnarsson 2009 & Qualitative & 20 & $75-90$ & $\begin{array}{l}\text { Sweden. } \\
\text { Social Work }\end{array}$ \\
\hline 21. & Hildon et al. 2010 & Quantitative & 174 & $68-82$ & $\begin{array}{l}\text { United Kingdom. } \\
\text { Psychology }\end{array}$ \\
\hline 22. & $\begin{array}{l}\text { Hutnik, Smith, and Koch } \\
2012\end{array}$ & Qualitative & 16 & $100+$ & $\begin{array}{l}\text { United Kingdom. } \\
\text { Psychology }\end{array}$ \\
\hline 23. & Jeon and Dunkle 2009 & $\begin{array}{l}\text { Observational } \\
\text { cohort }\end{array}$ & 193 & $85+$ & $\begin{array}{l}\text { Korea/USA. } \\
\text { Social Work }\end{array}$ \\
\hline 24. & $\begin{array}{l}\text { Jopp, Rott and Oswald } \\
2008\end{array}$ & Quantitative & 356 & $65-94$ & $\begin{array}{l}\text { USA/Germany. } \\
\text { Psychology }\end{array}$ \\
\hline 25. & $\begin{array}{l}\text { Klenk, Becker, and Rapp } \\
2010\end{array}$ & Register-based & & $65+$ & $\begin{array}{l}\text { Germany. } \\
\text { Medical Engineering }\end{array}$ \\
\hline 26. & Korhonen et al. 2012 & Register-based & & $80+$ & $\begin{array}{l}\text { Finland. } \\
\text { Medicine }\end{array}$ \\
\hline 27. & Krause 2004 & Quantitative & 1.518 & $65+$ & $\begin{array}{l}\text { USA. } \\
\text { Sociology }\end{array}$ \\
\hline 28. & $\begin{array}{l}\text { Lang, Baltes, and Wagner } \\
2007\end{array}$ & Quantitative & 1.125 & $20-90$ & $\begin{array}{l}\text { Germany. } \\
\text { Psychology. }\end{array}$ \\
\hline 29. & Larrson 2006 & Quantitative & $\begin{array}{l}2 \text { studies } \\
(\mathrm{n}=6,737)\end{array}$ & $65-99$ & $\begin{array}{l}\text { Sweden. } \\
\text { Social Work }\end{array}$ \\
\hline 30. & Lee and Dunkle 2010 & Quantitative & 213 & $85-94$ & $\begin{array}{l}\text { South Korea/USA. } \\
\text { Social Work }\end{array}$ \\
\hline 31. & Liang 2014 & Quantitative & 860 & $85+$ & $\begin{array}{l}\text { China. } \\
\text { Social Work }\end{array}$ \\
\hline 32. & Lloyd et al. 2014 & Quantitative & 34 & $70+$ & $\begin{array}{l}\text { United Kingdom. } \\
\text { Social Gerontology }\end{array}$ \\
\hline 33. & MacDonald et al. 2009 & Quantitative & 230 & $100+$ & $\begin{array}{l}\text { USA. } \\
\text { Economics }\end{array}$ \\
\hline 34. & $\begin{array}{l}\text { Mast, Azar, and Murrell } \\
2005\end{array}$ & Quantitative & 2.916 & $50+$ & $\begin{array}{l}\text { USA. } \\
\text { Psychology }\end{array}$ \\
\hline 35. & McGinnis 2009 & Experimental & 137 & $17-85$ & $\begin{array}{l}\text { USA. } \\
\text { Psychology }\end{array}$ \\
\hline 36. & Moe et al. 2012 & Quantitative & 120 & $80-101$ & $\begin{array}{l}\text { Norway/Sweden. } \\
\text { Nursing }\end{array}$ \\
\hline 37. & Momtaz et al. 2011 & Quantitative & 1.415 & $60-100$ & $\begin{array}{l}\text { Malaysia. } \\
\text { Gerontology }\end{array}$ \\
\hline
\end{tabular}




\begin{tabular}{|c|c|c|c|c|c|}
\hline 38. & $\begin{array}{l}\text { Muramatsu and Akiyama } \\
2011\end{array}$ & Expert opinion & & & $\begin{array}{l}\text { USA. } \\
\text { Gerontology }\end{array}$ \\
\hline 39. & Nesset al. 2005 & Quantitative & 1.099 & $52+$ & $\begin{array}{l}\text { USA. } \\
\text { Medicine }\end{array}$ \\
\hline 40. & Oswald et al. 2010 & Quantitative & 381 & $65-94$ & $\begin{array}{l}\text { Germany/ USA. } \\
\text { Psychology }\end{array}$ \\
\hline 41. & $\begin{array}{l}\text { Quentiart and Charpentier } \\
2012\end{array}$ & Qualitative & 25 & $65+$ & $\begin{array}{l}\text { Canada. } \\
\text { Sociology }\end{array}$ \\
\hline 42. & Roth et al. 2012 & Ethnographic & 47 & & USA. Sociology \\
\hline 43. & Thygesen et al. 2009 & Quantitative & 214 & $75+$ & $\begin{array}{l}\text { Norway. } \\
\text { Health Science }\end{array}$ \\
\hline 44. & Wastesson et al. 2012 & Register-based & 3.447 & $100+$ & $\begin{array}{l}\text { Sweden. } \\
\text { Medicine }\end{array}$ \\
\hline 45. & $\begin{array}{l}\text { Windsor, Burns, and Byles } \\
2011\end{array}$ & Quantitative & 552 & $55-74$ & $\begin{array}{l}\text { Australia/ USA. } \\
\text { Psychology }\end{array}$ \\
\hline 46. & Weyerer et al. 2013 & $\begin{array}{l}\text { Observational } \\
\text { cohort }\end{array}$ & 3.214 & $75+$ & $\begin{array}{l}\text { Germany. } \\
\text { Psychology }\end{array}$ \\
\hline 47. & Xie et al. 2008 & $\begin{array}{l}\text { Observational } \\
\text { cohort }\end{array}$ & 982 & $90+$ & $\begin{array}{l}\text { United Kingdom. } \\
\text { Biostatistics }\end{array}$ \\
\hline \multirow[t]{2}{*}{48.} & Zimmer 2005 & $\begin{array}{l}\text { Observational } \\
\text { cohort }\end{array}$ & 7.594 & $80-105$ & $\begin{array}{l}\text { China. } \\
\text { Sociology }\end{array}$ \\
\hline & $\mathrm{n}$ & 48 & & & \\
\hline
\end{tabular}

Source: Kydd et al. 2020

Figure 2 shows the 2018-2019 search rejected six articles, leaving three for review, only one of which was retained for this study. This article is reported on in the discussion. The updated search was to add a currency to the article, but the main focus of this article was to look at the 2003-2015 time period.

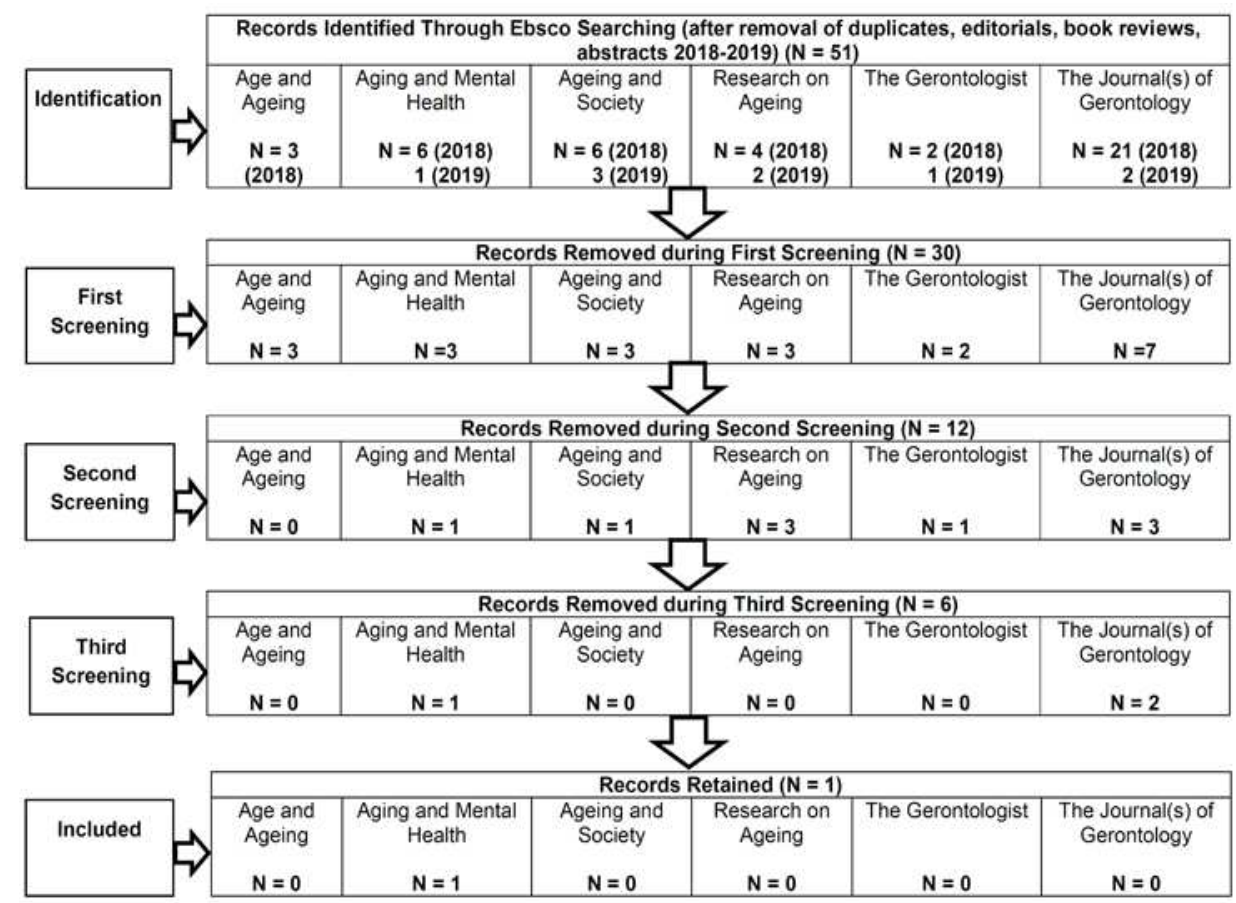

Figure 2: Flow Diagram of Article Selection 2018-2019 Source: Kydd et al. 2020 


\section{Results from the Analysis of Data (2003-2015)}

The detailed results are presented analyzing the forty-eight articles selected that met the strict inclusion criteria. Within each article it was interesting to see the differences in the actual ages ascribed to those classed as "oldest old" and those classed as "fourth age". Consensual categories included octogenarians, nonagenarians, and centenarians. Further differences were found in some articles in relation to (i) the discourses on the oldest old and fourth age groups, (ii) the various terms and their use describing the oldest old and fourth age, and (iii) the various age stratifications used to define oldest old and fourth age. These differences are reported in Table 2.

Table 2: Discourses on Terminology and the Oldest Old Age Definitions Found in the Articles

\begin{tabular}{|c|c|c|c|c|c|c|c|c|c|c|c|}
\hline & \multicolumn{5}{|c|}{ Terminology } & \multicolumn{6}{|c|}{ Oldest old age definition } \\
\hline No. & $\begin{array}{l}\text { Fourth } \\
\text { age }\end{array}$ & $\begin{array}{l}\text { Very elderly/ } \\
\text { very old/very } \\
\text { old adults/ } \\
\text { very old } \\
\text { individuals/ } \\
\text { very old age } \\
\text { group } \\
\end{array}$ & $\begin{array}{l}\text { Oldest old } \\
\text { / oldest } \\
\text { old adults }\end{array}$ & $\begin{array}{l}\text { Older age } \\
\text { group / Old- } \\
\text { old / Older } \\
\text { adults with } \\
\text { advancing } \\
\text { age }\end{array}$ & $\begin{array}{l}\text { Octo/ } \\
\text { Nona/ } \\
\text { Cent/ } \\
\text { Extreme }\end{array}$ & $75+$ & $80+$ & $85+$ & $90+$ & $\begin{array}{l}90- \\
100\end{array}$ & $\begin{array}{l}100 \\
+\end{array}$ \\
\hline 1. & & & $\mathrm{x}$ & & & & & $\mathrm{x}$ & & & \\
\hline 2. & & & $\mathrm{x}$ & & & & $\mathrm{x}$ & & & & \\
\hline 3. & & & $\mathrm{x}$ & & & & $\mathrm{x}$ & & & & \\
\hline 4. & & & $\mathrm{x}$ & & & & $\mathrm{x}$ & & & & \\
\hline 5. & & $\mathrm{x}$ & & & & & & $\mathrm{x}$ & & & \\
\hline 6. & & & $\mathrm{x}$ & & & & & $\mathrm{x}$ & & & \\
\hline 7. & $\mathrm{x}$ & & & & & & & & & & \\
\hline 8. & & & $\mathrm{x}$ & & & & & $\mathrm{x}$ & & & \\
\hline 9. & & $\mathrm{x}$ & $\mathrm{x}$ & & & & & & $\mathrm{x}$ & & \\
\hline 10. & & $\mathrm{x}$ & & $\mathrm{x}$ & & & $\mathrm{x}$ & & & & \\
\hline 11. & & & & $\mathrm{x}$ & & & & $\mathrm{x}$ & & & \\
\hline 12. & & & $\mathrm{x}$ & & & & & $\mathrm{x}$ & & & \\
\hline 13. & & & $\mathrm{x}$ & & & & & $\mathrm{x}$ & & & \\
\hline 14. & & & & $\mathrm{x}$ & & & & & & & \\
\hline 15. & & $\mathrm{x}$ & & & & & $\mathrm{x}$ & & & & \\
\hline 16. & & $\mathrm{x}$ & $\mathrm{x}$ & & & & $\mathrm{x}$ & & & & \\
\hline 17. & & & $\mathrm{x}$ & $\mathrm{x}$ & & & & $\mathrm{x}$ & & & \\
\hline 18. & & & $\mathrm{x}$ & & & $\mathrm{x}$ & & & & & \\
\hline 19. & & $\mathrm{x}$ & & & & & & $\mathrm{x}$ & & & \\
\hline 20. & $\mathrm{x}$ & & $\mathrm{x}$ & & & $\mathrm{x}$ & & & & & \\
\hline 21. & & & & $\mathrm{x}$ & & & & & & & \\
\hline 22. & & & & & $\mathrm{x}$ & & & & & & $\mathrm{x}$ \\
\hline 23. & & $\mathrm{x}$ & $\mathrm{x}$ & & & & & $\mathrm{x}$ & & & \\
\hline 24. & $\mathrm{x}$ & $\mathrm{x}$ & $\mathrm{x}$ & $\mathrm{x}$ & & & $\mathrm{x}$ & & & & \\
\hline 25. & & & $\mathrm{x}$ & & & & & & $\mathrm{x}$ & & \\
\hline
\end{tabular}




\begin{tabular}{|c|c|c|c|c|c|c|c|c|c|c|c|}
\hline 26. & & & $\mathrm{x}$ & & & & & & $\mathrm{x}$ & & \\
\hline 27. & & $\mathrm{X}$ & $\mathrm{X}$ & & & & & $\mathrm{X}$ & & & \\
\hline 28. & & $\mathrm{x}$ & & & & & & & & $\mathrm{x}$ & \\
\hline 29. & & & $\mathrm{x}$ & & & & $\mathrm{x}$ & & & & \\
\hline 30. & & & $\mathrm{x}$ & & & & & $\mathrm{x}$ & & & \\
\hline 31. & & & $\mathrm{x}$ & & & & & $\mathrm{x}$ & & & \\
\hline 32. & $\mathrm{x}$ & & & & & $\mathrm{X}$ & & & & & \\
\hline 33. & & & & & $\mathrm{X}$ & & & & & & $\mathrm{X}$ \\
\hline 34. & & & $\mathrm{x}$ & & & & & $\mathrm{x}$ & & & \\
\hline \multicolumn{12}{|l|}{35.} \\
\hline 36. & & & $\mathrm{x}$ & & & & $\mathrm{x}$ & & & & \\
\hline 37. & & & $\mathrm{x}$ & & & & & $\mathrm{x}$ & & & \\
\hline 38. & & & $\mathrm{x}$ & & & & & & & & $\mathrm{X}$ \\
\hline 39. & & & $x$ & & & & & $\mathrm{x}$ & & & \\
\hline 40. & & $\mathrm{x}$ & $\mathrm{x}$ & & & & $\mathrm{x}$ & & & & \\
\hline 41. & & & $\mathrm{X}$ & & & & & $\mathrm{x}$ & & & \\
\hline 42. & $\mathrm{x}$ & & & & & & & & & & $\mathrm{x}$ \\
\hline 43. & & & & $\mathrm{x}$ & & & & & & & \\
\hline 44. & & & & & $\mathrm{x}$ & & & & & & $\mathrm{x}$ \\
\hline \multicolumn{12}{|l|}{45.} \\
\hline 46. & & & $\mathrm{x}$ & & & & & $\mathrm{x}$ & & & \\
\hline 47. & & $\mathrm{x}$ & $\mathrm{x}$ & & & & & & $\mathrm{x}$ & & \\
\hline 48. & & & $\mathrm{x}$ & & & & $\mathrm{x}$ & & & & \\
\hline$n$ & 4 & 12 & 31 & 7 & 3 & 3 & 11 & 18 & 4 & 1 & 5 \\
\hline
\end{tabular}

Legend: ${ }^{1}$ Octo: Octogenarians, Nona: Nonagenarians, Cent: Centenarians, Extreme: Extreme Old Age Source: Kydd et al. 2020

The results highlight the point that "old age" studies have little consensus on what age constitutes the "oldest old" or "fourth age." In searching for these terms in a limited selection of articles, many other derivative terms used to describe "older people" were found. As stated above, these are reported upon as (i) the discourses on the oldest old and fourth age groups, (ii) the various terms and their use describing the oldest old and fourth age, and (iii) the various age stratifications used to define oldest old and fourth age.

\section{Discourses on the Oldest Old and Fourth Age Groups}

In the articles examined, the oldest old and fourth age can be found as commencing at 75 and over, 80 and over, 85 and over, or 90 and over. In three papers, the "oldest old" were classed as under 80 years of age (Gunnarsson 2009; Lloyd et al. 2014; Fastame and Penna 2014). Lloyd et al. (2014) referred to people aged 75 and over as being in the "fourth age." Similarly, Gunnarsson (2009) referred to those aged 75 and over as being in the "fourth age," "the oldest old," and the "frail elderly." Fastame and Penna (2014) initially defined the "oldest old" as 85 and over, but then described the 75 and over age group as the "oldest old."

Eleven papers defined the 80 and over age group as the "very-old," "oldest-old," "oldest old adulthood," and "very elderly" (Birditt 2014; Birditt and Fingerman 2003; Engelter, Bonati, and Lyrer 2006; Erlangsen et al. 2004; Moe et al. 2013; Oswald et al. 2011; Zimmer 2005; Jopp, 
Rott, and Oswald 2008; Chipperfield 2008; Berg et al. 2006; Larsson 2006). Erlangsen et al. (2004) implied that 80 and over defined the "oldest old." Zimmer (2005) and Engelter et al. (2006) define the "oldest old" as 80 and over but with no rationale. Other authors, however, provided clear age stratifications and gave the definition of the "oldest old" as 80 and over.

The most frequent chronological definition of the oldest old was "85 and over," which was used in just over a third of the papers $(\mathrm{n}=18)$ (Beel-Bates, Ingersoll-Dayton, and Nelson 2007; Bowling and Grundy 2009; Braungart Fauth et al. 2007; Cicirelli 2006; Conroy et al. 2014; Fastame et al. 2013; Gott et al. 2006; Jeon and Dunkle 2009; Krause 2004; Lee and Dunkle 2010; Liang 2014; Mast, Azar, and Murrell 2005; Momtaz et al. 2011; Ness et al. 2005; Quéniart and Charpentier 2012; Weyerer et al. 2013; Bowling et al. 2005). Six of these papers (Beel-Bates, Ingersoll-Dayton, and Nelson 2007; Fastame et al. 2013; Gott et al. 2006; Lee and Dunkle 2010; Weyerer et al. 2013; Bowling et al. 2005) clearly defined the "oldest old" as those aged 85 years and over with reference to the literature. Six papers defined the "oldest old" as those aged 85 and over, but did not provide a rationale for selecting this age (Beel-Bates, Ingersoll-Dayton, and Nelson 2007; Bowling and Grundy 2009; Fastame et al. 2013; Gott et al. 2006; Jeon and Dunkle 2009; Weyerer et al. 2013). Cicirelli (2006) inferred that those aged 85 and over must be the "oldest old," as did Conroy et al. (2014) who stated that the 85 and over age group were those who were identified in local data to have the highest incidence of health care usage. However, the demographics of the local data were not referred to. Weyerer et al. (2013) talked of the "oldest old" as 85 and over, but only once in the key points and later in the paper referred to those aged 75 and over as the "older old."

Four papers spoke of those aged 90 and over. Bronnun-Hansen et al. (2009) using the term "oldest old" only in the title of their paper, but they did cite two references to support using the term "very old" when referring to people aged 90 and over. The remaining three papers referred to age 90 and over as the "oldest old" but provided no rationale (Korhonen et al. 2012; Klenk, Becker, and Rapp 2010; Xie et al. 2008).

Two articles referred to centenarians, with the term "extreme old age" (Hutnik, Smith, and Koch 2012; MacDonald et al. 2009) and MacDonald et al. (2009) added the term "nearcentenarians." Lang et al. (2007) referred to the 90-100 year olds as "very old people," whereas Wastesson et al. (2012) simply referred to octogenarians, nonagenarians, and centenarians

\section{The Various Terms and Their Use Describing the Oldest Old and Fourth Age}

The authors found not only different age groups for the "oldest old" and "fourth age," but also variations in the terminology itself. The most frequent term used was "the oldest old" $(\mathrm{n}=31)$, followed by "the very old" $(\mathrm{n}=12)$ and the "fourth age" $(\mathrm{n}=4)$. Several variations of the "the very old" were used, such as "very elderly," "very old adults," "very old age group," "very old age," "very old elders," "very old individuals," "very old people," and "very old persons" (Bowling and Grundy 2009; Gott et al. 2006; Jeon and Dunkle 2009; Krause 2004; Erlangsen et al. 2004; Moe et al. 2013; Oswald et al. 2011; Bronnum-Hansen et al. 2009; Xie et al. 2008; Lang, Baltes, and Wagner 2007; Jopp, Rott, and Oswald 2008; Chipperfield 2008). Birditt and Fingerman (2003) spoke of "the oldest old adulthood," which served to show how diverse the sub-categories of "oldest old and "fourth age" have become.

Differences in the use of terms were found not only between the papers but also within the papers. The terminology varied in ten papers, including "very old," "oldest old," "very old adults/elders/group/individuals/people," "elder individuals," "fourth age," "frail elderly" and "the very oldest age" (Fastame et al. 2013; Jeon and Dunkle 2009; Krause 2004; Erlangsen et al. 2004; Oswald et al. 2011; Gunnarsson 2009; Bronnum-Hansen et al. 2009; Xie et al. 2008; Jopp, Rott, and Oswald 2008; Chipperfield 2008). For example, Bronnun-Hansen et al. (2009) used the term "oldest old" only in the title of their paper, but later in the paper used the terms "very old," "elder individuals," "very old individuals," and then "nonagenarians" when referring to people in their nineties. 
The American studies quite consistently used the term "the oldest old" (Beel-Bates, Ingersoll-Dayton, and Nelson 2007; Braungart Fauth et al. 2007; Lee and Dunkle 2010; Mast, Azar, and Murrell 2005; Ness et al. 2005; Birditt 2014; Birditt and Fingerman 2003; Lloyd et al. 2014; Berg et al. 2006; Muramatsu and Akiyama 2011). Articles written in partnership between American and German (Oswald et al. 2011) and American and Canadian researchers (Chipperfield 2008) used the term "very old." One American paper also used the term "fourth age" (Roth et al. 2012). British research used a variety of terms: "fourth age" (Gilleard and Higgs 2013; Lloyd et al. 2014; Duncan 2008); “oldest old" (Bowling et al. 2005; Xie et al. 2008); "very elderly" (Bowling and Grundy 2009); and "very old" (Xie et al. 2008; Gott et al. 2006). One British, one American, and one Swedish study used the term "centenarians," due to the nature of the studies focusing on people around 100 years and older (Hutnik, Smith, and Koch 2012; MacDonald et al. 2009; Wastesson et al. 2012). Other articles from European research (Danish, Irish, Swiss, Italian, German, Swedish, Finnish, Norwegian) used a variety of terms, most frequently the "oldest old" (Fastame et al. 2013; Weyerer et al. 2013; Fastame and Penna 2014; Korhonen et al. 2012; Klenk, Becker, and Rapp 2010). Other terms used were the "very old" (Fastame and Penna 2014; Lang, Baltes, and Wagner 2007); those aged "85 years or more" (Windsor, Burns, and Byles 2013); the "very elderly" (Moe et al. 2013); "fourth age" (Fastame and Penna 2014); and "older age group" (McGinnis 2009). One study from New Zealand and one from Israel used the term "fourth age(s)" (Boyes 2013), whilst one article from China and one from Malaysia used the term "oldest old" (Momtaz et al. 2011; Quéniart and Charpentier 2012).

On close inspection of the chronological definition of the oldest age group by the region, no substantial variability in definitions of this age group was found. In addition, the assessment of chronological definitions of oldest old age by the study type and a discipline did not demonstrate any substantial differences. The only difference observed was that psychological studies tend to define more frequently the oldest age group at 80 years of age, while all other disciplines most frequently defined it at 85 years (Table 3). One of the reasons for no geographical differences could be the over representativeness of the studies in this sample conducted within developed counties, although the search terms used were not limited to any geographic region.

Table 3: Demographic Description of the Research in Relation to the Region, Discipline and Study Type

\begin{tabular}{|c|c|c|c|c|c|}
\hline & Median Age & Mean Age & Range & $\begin{array}{l}\text { Standard } \\
\text { Deviation }\end{array}$ & Variance \\
\hline \multicolumn{6}{|l|}{ Region } \\
\hline Europe $(n=20)$ & 85 & 85 & $75-100$ & 7.071 & 50.000 \\
\hline North America $(n=12)$ & 85 & 87 & $80-100$ & 7.833 & 61.364 \\
\hline Asia $(n=2)$ & 82.5 & 82.5 & $80-85$ & 3.536 & 12.500 \\
\hline Malaysia $(\mathrm{n}=1)$ & 85 & 85 & 85 & . & . \\
\hline $\begin{array}{l}\text { North America \& Europe } \\
(\mathrm{n}=4)^{1}\end{array}$ & 85 & 81.2 & $80-85$ & 2.500 & 6.250 \\
\hline $\begin{array}{l}\text { North America \& Asia } \\
(\mathrm{n}=2)^{1}\end{array}$ & 85 & 85. & $80-85$ & 0.000 & 0.000 \\
\hline \multicolumn{6}{|l|}{ Discipline } \\
\hline Psychology (n=13) & 80 & 83.1 & $75-100$ & 5.965 & 35.577 \\
\hline Social Work $(\mathrm{n}=6)$ & 85 & 82.5 & $75-85$ & 4.183 & 17.500 \\
\hline Medicine $(n=6)$ & 85 & 87.5 & $80-100$ & 6.892 & 47.500 \\
\hline Sociology $(n=5)$ & 85 & 86 & $80-100$ & 8.216 & 67.500 \\
\hline Other $(\mathrm{n}=11)$ & 85 & 87.7 & $75-100$ & 7.538 & 56.818 \\
\hline
\end{tabular}




\begin{tabular}{|l|c|c|c|c|c|}
\hline \multicolumn{1}{|c|}{ Study Type } \\
\hline Quantitative (n=21) & 85 & 82.9 & $75-100$ & 5.141 & 26.429 \\
\hline $\begin{array}{l}\text { Observational cohort } \\
\text { study (n=8) }\end{array}$ & 85 & 85.6 & $80-90$ & 3.204 & 10.268 \\
\hline Qualitative (n=4) & 85 & 86.2 & $75-100$ & 10.308 & 106.250 \\
\hline Register - based (n=4) & 90 & 90 & $80-100$ & 8.165 & 66.667 \\
\hline Other $(\mathrm{n}=4)$ & 92.5 & 91.2 & $80-100$ & 10.308 & 106.250 \\
\hline
\end{tabular}

Legend: ${ }^{1}$ The Studies that were Conducted in Cooperation Between Countries in Different Regions Source: Kydd et al. 2020

\section{The Various Age Stratifications Used to Define Oldest Old and Fourth Age}

Further differences in the use of the terms were found in relation to age stratifications. Bowling and Grundy (2009) referred to 65-85 as "later life and "older age" and those aged 85 and over as "very elderly"; whereas Conroy et al. (2014) gave age stratifications as 16-64, then 65-74, 7584 , and then 85 and over. Similarly Mast et al. (2005) used age stratifications of 50-64; 65-74; 75-84; and those age 85 and over, who were defined as the "oldest old." Momtaz et al. (2011) used $60-64 ; 75-84$; and 85 and over, again defining those 85 and over as the "oldest old." Cicirelli (2006) gave classifications of age as "young old" 60-74 and "mid old" 75-84, with no mention of what the 85+ population would be called; and McGinnis (2009) used the terms "young old" and "old old" giving the ages of 67-73 and 80-96, respectively.

Jopp et al. (2008) defined ages in five-year age bands, starting with 65-69 and ending with 90-94 (65-79 being the young old, and 76-94 being the old old). A further article defined the 80 and over age group as the "old-old" "very old" and "elder individuals" with 65-80 classed as the "young old" (Oswald et al. 2011), however, clear definitions were given for the distinctions, with reference to the literature. Ness et al. (2005) gave tables with age bands from 52-64; 65-79 and then eighty years and over. Fastame and Penna (2014) used the age bands 75-99 years and Thygesen et al. (2009) used 75 and over to mean "older people," with no cut off age. Bowling et al. (2005), Larsson (2006) and Quéniart and Charpentier (2012) all used age stratifications from the age of 65 , with Bowling et al. (2005) referring to the "third age" and the "oldest old." Lloyd et al. (2014) referred to people below the age of 75 as being in the "third age," with those aged 75 and over as being in the "fourth age." Gunnarsson (2009) referred to the over $75 \mathrm{~s}$ as the "fourth age" but does align these terms with a cohort aged 75-90 that she used in her study. Windsor et al. (2013) described a population-based sample as "midlife" aged 55-59; "young old" aged 60-74; and "old old" as 75 and over; whereas Birditt and Fingerman (2003), in studying a group aged 13-99, referred to "adolescents" as 13-16; "young adulthood" 20-29; "middle adulthood" 40-49; "young old adulthood" 60-69; and "oldest old adulthood" as 80 and over. Birditt (2014) used these age groups in a later paper, which gave consistency to her work. Lang et al. (2007) gave age bands of 20-34, 35-49, 50-64, 65-79, and 80 and over, with no rationale, but they did refer to the 90 - to 100 -year-olds as "very old people." Finally, seven articles referred to "old age," "very old persons," "third age," and "fourth age," giving differing broad age bands, or simply using the term "oldest old" and/or "fourth age" (Bowling et al. 2005; Boyes 2013; Duncan 2008; Jopp, Rott, and Oswald 2008; Roth et al. 2012; Chipperfield 2008; Muramatsu and Akiyama 2011). For example, Boyes (2013) used the term "fourth age" in his study, not indicating a specific age band for the term, but did give specific age bands for his study: 63 to 80 years old and 54 to 83 years old. 


\section{Discussion}

The ultimate aim of this work is to call for the consistent use of age bands of ten-year cohorts, with words that have a universal meaning (septuagenarians, octogenarians, etc.). This would serve to give a dependent variable in ageing research studies and avoid the ageist connotations bound to the terms "older people" and "fourth age." Ageist language promotes ageist attitudes, and such attitudes have concrete consequences in relation to how people over 60 are viewed. So, in removing negative social constructs about aging and solely referring to factual cohorts, advanced years can be viewed as a period of personal growth, creativity, and productivity, as well as a period that can involve losses.

The one article (Etxeberria, Etxebarria, and Urdaneta 2018) sourced from the 2018-2019 search has shown there has been little progression in gaining a consensus of the age of those in the fourth age or oldest old group. The authors in this selected paper conducted a study $(\mathrm{n}=257)$ with older people and used age bands 65-74, 75-84, 85-94, and 95-104. They reported on the over $85 \mathrm{~s}$ as the "oldest old." This limited update shows that there is still no consensus on the terms the "fourth age" or "oldest old" or indeed those classed as "older people." In fact, there is a great variety of terms indicating the "oldest old" or "fourth age" in the articles examined, and there is no consistency or agreement among the authors on the definitions of the terms, or on the age bands relating to the terms. These findings also showed no consensus between disciplines or countries.

Although only a pilot study, it is interesting to note that in this review of forty-eight papers, little influence was found on the use of terms and age definitions by different disciplines. For example, seventeen articles were sourced from psychology, ranging from 2003 to 2014. These papers variously used each of the five descriptions of terminology contained in Table 2, and each of the six oldest old age definitions also described in Table 2. Similarly, six articles from social work (2006 to 2014) used oldest-old most frequently, but also referred to the "very elderly" and the "fourth age." The age bands were used inconsistently, including $85+$ years, $80+$ years, and $75+$ years. Other disciplines (seen in Table 1) included gerontology (3), economics (1), biostatistics (1), education (1), public health (1), medical engineering (1), social science (2), medicine (8), sociology (3), nursing (2), health science (1), and social gerontology (1). The papers reviewed came from fifteen countries and, again, there was no consensus between same country studies.

Yet for comparative studies and gerontological research, it is important to make a clear distinction among age groups in old age and equally important to remove the negative connotations that come with pejorative terms. Context, culture, education, health status, socioeconomic status, and many other variables dictate how a person ages. Resilience, for example, is a studied characteristic that can have a relevant impact on the ageing process (Janssen, Abma, and Van Regenmortel 2012; Zimmermann and Grebe 2014). So, referring to people 65 years old in the same breath as a person of 98 - as in both are called older people - is problematic. Physiological changes take place as individuals age but each person ages in a unique manner. Some older people may experience a long and continuous decline of functional abilities, whereas others may enjoy a long period of health followed by a rapid decline leading to death. There are of course many other aging trajectories between these two extreme types.

If old age has such variety, then it makes little sense to define the nebulous concept of "older people" and divide it to create two further nebulous concepts of a third age and fourth age. The former implies activity and engagement and the latter implies frailty. A 90-year-old person can be independent and active; a 70-year-old person can be severely disabled.

In the WHO 2017 Global Strategy and Action Plan on Ageing and Health (World Health Organization Health Assembly 2017, 10), objective thirteen on combating ageism states, "a key feature will be to break down arbitrary age-based categorizations (such as labelling those over a certain age as old). These overlook the great diversity of ability at any given age and can lead to 
simplistic responses based on stereotypes of what that age implies." As highlighted earlier, the categories "fourth age" or "oldest old" seem mainly to have moved the negative connotations into the over 80 age group, which fail to address the WHO call to break down arbitrary age classifications. It can be argued that at times, differences among individual older people are more relevant than differences among age cohorts (Baars 2010). Yet, it could also be argued that those within age cohorts share the same period in time and the same life conditions in specific contexts. For example, it is now common in Europe that many people aged 65 years old will still be in the workplace. This fact underlines the relevance of researching cohorts of people in their contexts. The change in retirement ages has meant that workplaces now need to address issues concerning an ageing workforce. The point is that the current inconsistences make researching older populations difficult, a point made by Cohen-Mansfield et al. (2013), who speak of the problem of comparing cohorts of "older people" due to the inconsistent use of age stratifications by researchers and policy makers in the field of gerontology.

The authors call for definitive age groupings of 10-year cohorts. These cohorts are already named and referring to septuagenarians or octogenarians is without bias or prejudice - they are facts. This provides educators, researchers, and policy makers with a shared understanding of the groups being referred to. There are a growing number of octogenarians, nonagenarians, and centenarians that will make up around 20 percent of the European population in 2050. Gaining consensus regarding studies on ten-year cohort groupings means that studies can be comparable. For example, older women represent the majority of those aged 85 and over, and they have generally poorer health conditions than older men of the same age. Yet to build on these findings with studies that report on the health of people over 70 or 80 or 90 is not possible.

This pilot study presents certain limitations but also some important points. The study did not take into account differences in the use of term "oldest old" in relation to: 1) time span: the ongoing changes in the use of the term in the gerontological field over the thirteen-year period were not considered; 2) different disciplines: the disciplines of the main authors of the papers reviewed were noted and demonstrated no agreement among disciplines, but this is purely anecdotal due to the limited search conducted; 3) different countries and cultures: only partial differences among countries and culture in the use of the different terms to indicate the "oldest old" were highlighted as in the different use of the term in American and British articles were noted. The study was limited to six gerontological journals, and excluded longitudinal studies, veteran studies and biomedical articles, which the authors acknowledge was very limited. The sample should be broadened in terms of number of journals included and time span; the sample should also include articles on old age taken by journals in different disciplines (medicine, dociology, psychology, etc.). Moreover the articles examined referred mainly to developed countries; thus, further research needs to include a broader range of countries.

Overall, the main strength of this study is methodological. It discusses the problem of terminology using the gerontological literature as data. It suggests an empirical approach in relation to the issue of terminology. The authors examined articles in the gerontological literature to look at the actual use of the terms "oldest old" and "fourth age" and found no accordance on the use of these terms and in relation to the correspondence with age groups.

The authors suggest using age bands that define cohorts. The 60-9 group as sexagenarians, the $70-79$ as septuagenarians, the $80-89$ as octogenarians, the $90-99$ as nonagenarians, and, of course, the 100-year-olds as centenarians. Studies would then all be referring to the same age group, which would facilitate comparison and identifying differences between the different cohorts, and also differences among individuals within the same cohorts. In applying a factual chronological age band, potentially pejorative phrases such as "very elderly," "old old," "very old" would no longer be needed. Perhaps age categories can be useful in defining all populations. Such categorization would remove the words "young" or "old" from common parlance and serve to describe cohorts over the life course. These would include denarians (10-19), vicenarians (20- 
29), tricenarians (30-39), quadragenarians (40-49), and quinquagenarians (50-59). These terms are not in use and were located on medicinenet.com (2017).

\section{Conclusion}

In this article, the aim is to raise awareness of the issues concerning defining the oldest old and the ageist connotation of the term. Variations in age grouping and terminology referring to the oldest old or fourth age in forty-eight articles in the six top social gerontology journals were discussed. The findings showed that definitions of oldest old have not been consistently addressed in the literature. There is, however, agreement that there are no commonalities to be seen in those aged 60 to 110 years and over, and the authors argue that age stratification is necessary to break up this 50- to 60-year period of being termed "old." The different age groupings used to define the fourth age and the oldest old appear to impinge on researching and planning services for this population. In using the terms octogenarians, nonagenarians, and centenarians, there is a clear understanding of the age groups of the populations, without using the poorly defined and value-laden terms of oldest-old and fourth age.

\section{Funding}

The researchers received no funding to conduct this study.

\section{REFERENCES}

Age International. 2015. Facing the Facts: The Truth about Ageing. London: Age International.

Andrew, Melissa K. 2015. "Frailty and Social Vulnerability." Interdisciplinary Topics in Gerontology and Geriatrics 41: 186-95. https://doi.org/10.1159/000381236.

Association of Directors of Public Health. 2018. Policy Position: Healthy Ageing. London: Association of Directors of Public Health. http://www.adph.org.uk/wpcontent/uploads/2018/05/ADPH-Position-Statement-Healthy-Ageing.pdf.

Baars, Jan 2010. "Time and Aging: Enduring and Emerging Issues." In International Handbook of Social Gerontology, edited by D. Dannefer and C. Phillipson, 367-76. New York: SAGE Publishers.

Baars, Jan. 2007. "Chronological Time and Chronological Age: Problems of Temporal Diversity." In Aging and Time: Multidisciplinary Perspectives, edited by Jan Baars and Henk Visser, 1-13. Amityville, NY: Baywood Publishing.

Beel-Bates, Cindy A., Berit Ingersoll-Dayton, and Erika Nelson. 2007. "Deference as a Form of Reciprocity among Residents in Assisted Living." Research on Aging 29 (6): 626-43. https://doi.org/10.1177/0164027507305925.

Berg, Anne Ingeborg, Linda Bjork Hassing, Gerald E. McClearn, and Boo Johansson. 2006. "What Matters for Life Satisfaction in the Oldest-Old?" Aging \& Mental Health 10 (3): 257-64. https://doi.org/10.1080/13607860500409435.

Birditt, Kira S. 2014. "Age Differences in Emotional Reactions to Daily Negative Social Encounters." Journals of Gerontology Series B: Psychological Sciences and Social Sciences 69 (4): 557-66. https://doi.org/10.1093/geronb/gbt045.

Birditt, Kira S., and Karen L. Fingerman. 2003. "Age and Gender Differences in Adults" Descriptions of Emotional Reactions to Interpersonal Problems." Journals of Gerontology. Series B, Psychological Sciences and Social Sciences 58 (4): P237-45. https://doi.org/10.1093/geronb/58.4.p237.

Bowling, Ann, and Emily Grundy. 2009. "Differentials in Mortality up to 20 Years after Baseline Interview among Older People in East London and Essex." Age and Ageing 38 (1): 5155. https://doi.org/10.1093/ageing/afn220. 
Bowling, Ann, Sharon See-Tai, Shah Ebrahim, Zahava Gabriel, and Priyha Solanki. 2005. "Attributes of Age-Identity." Ageing \& Society 25 (4): 479-500. https://doi.org/10.1017/S0144686X05003818.

Boyes, Mike. 2013. "Outdoor Adventure and Successful Ageing." Ageing \& Society 33 (4): 64465. https://doi.org/10.1017/S0144686X12000165.

Braungart Fauth, Elizabeth, Steven H. Zarit, Bo Malmberg, and Boo Johansson. 2007. "Physical, Cognitive, and Psychosocial Variables from the Disablement Process Model Predict Patterns of Independence and the Transition into Disability for the Oldest-Old." Gerontologist 47 (5): 613-24.

Bronnum-Hansen, Henrik, Inge Petersen, Bernard Jeune, and Kaare Christensen. 2009. "Lifetime According to Health Status among the Oldest Olds in Denmark." Age and Ageing 38 (1): 47-51. https://doi.org/10.1093/ageing/afn239.

Caljouw, Monique A. A., Saskia J. M. Kruijdenberg, Anton J. M. de Craen, Herman J. M. Cools, Wendy P. J. den Elzen, and Jacobijn Gussekloo. 2013. "Clinically Diagnosed Infections Predict Disability in Activities of Daily Living among the Oldest-Old in the General Population: The Leiden 85-plus Study." Age and Ageing 42 (4): 482-88. https://doi.org/10.1093/ageing/aft033.

Chipperfield, Judith G. 2008. "Everyday Physical Activity as a Predictor of Late-Life Mortality." Gerontologist 48 (3): 349-57. https://doi.org/10.1093/geront/48.3.349.

Cho, Jinmyoung, Peter Martin, Leonard W. Poon, and Georgia Centenarian Study. 2015. "Successful Aging and Subjective Well-Being among Oldest-Old Adults." Gerontologist 55 (1): 132-43. https://doi.org/10.1093/geront/gnu074.

Cicirelli, Victor G. 2006. "Fear of Death in Mid-Old Age." Journals of Gerontology. Series B, Psychological Sciences and Social Sciences $61 \quad$ (2): 75-81. https://doi.org/10.1093/geronb/61.2.p75.

Cohen-Mansfield, J., Dov Shmotkin, Zvia Blumstein, Aviva Shorek, Nitza Eyal, and Haim Hazan. 2013. "The Old, Old-Old, and the Oldest Old: Continuation or Distinct Categories? An Examination of the Relationship between Age and Changes in Health, Function, and Wellbeing." International Journal of Aging and Human Development, 77(1): 37-57. https://doi.org/10.2190\%2FAG.77.1.c.

Conroy, Simon P., Kharwar Ansari, Mark Williams, Emily Laithwaite, Ben Teasdale, Jeremy F. Dawson, Suzanne Mason, and Jay Banerjee. 2014. "A Controlled Evaluation of Comprehensive Geriatric Assessment in the Emergency Department: The "Emergency Frailty Unit."” Age and Ageing 43 (1): 109-14. https://doi.org/10.1093/ageing/aft087.

Cotter, Paul E., Marion Simon, Colin P. Quinn, and Shaun T O'Keeffe. 2009. "Changing Attitudes to Cardiopulmonary Resuscitation in Older People: A 15-year Follow-Up Study." Age and Ageing 38: 200-05. https://doi.org/10.1093/ageing/afn291.

Duncan, Colin. 2008. "The Dangers and Limitations of Equality Agendas as Means for Tackling Old-Age Prejudice." Ageing \& Society $28 \quad$ (8): 1133-58. https://doi.org/10.1017/S0144686X08007496.

Engelter, Stefan T., Leo H. Bonati, and Philippe A. Lyrer. 2006. "Intravenous Thrombolysis in Stroke Patients of $>$ or $=80$ versus $<80$ Years of Age--a Systematic Review across Cohort Studies." Age and Ageing 35 (6): 572-80. https://doi.org/10.1093/ageing/afl104.

Erlangsen, Annette, Bernard Jeune, Unni Bille-Brahe, and James W. Vaupel. 2004. "Loss of Partner and Suicide Risks among Oldest Old: A Population-Based Register Study." Age and Ageing 33 (4): 378-83. https://doi.org/10.1093/ageing/afh128.

Etxeberria, Igone, Itziar Etxebarria, and Elena Urdaneta. 2018. "Profiles in Emotional Aging: Does Age Matter?" Aging \& Mental Health 22 (10): 1304-12. https://doi.org/10.1080/13607863.2017.1286450.

Eurostat. 2019a. "Population on 1 January by Age Group and Sex [Demo_pjangroup]." Eurostat. https://ec.europa.eu/eurostat/data/database. 
2019b. "Population: Structure Indicators [Demo_pjanind]." Eurostat. https://ec.europa.eu/eurostat/data/database.

Fastame, Maria Chiara, Maria Pietronilla Penna, E. S. Rossetti, and M. Agus. 2013. "Perceived Well-Being and Metacognitive Efficiency in Life Course: A Developmental Perspective." Research on Aging 35 (6): 736-49. https://doi.org/10.1177/0164027512462411.

Fastame, Maria Chiara, and Maria Pietronilla Penna. 2014. "Psychological Well-Being and Metacognition in the Fourth Age: An Explorative Study in an Italian Oldest Old Sample." Aging \& Mental Health 18 (5): 648-52. https://doi.org/10.1080/13607863.2013.866635.

George, Linda. 2011. "The Third Age: Fact or Fiction - and Does It Matter?" In Gerontology in the Era of the Third Age: Implications and Next Steps, edited by D. C. Carr and K. Komp, 245-59. New York: Springer Publishing Company.

Gilleard, Chris, and Paul Higgs. 2013. "The Fourth Age and the Concept of a "Social Imaginary": A Theoretical Excursus." Journal of Aging Studies 27 (4): 368-76. https://doi.org/10.1016/j.jaging.2013.08.004.

Gilleard, Chris, and Paul Higgs. 2015. Rethinking Old Age: Theorizing the Fourth Age. London: Palgrave Macmillan.

Gott, Merryn, Sarah Barnes, Chris Parker, Sheila Payne, David Seamark, Salah Gariballa, and Neil Small. 2006. "Predictors of the Quality of Life of Older People with Heart Failure Recruited from Primary Care." Age and Ageing 35 (2): 172-77. https://doi.org/10.1093/ageing/afj040.

Guerrero-Bote, Vicente P., and Félix Moya-Anegón. 2012. "A Further Step Forward in Measuring Journals" Scientific Prestige: The SJR2 Indicator.” Journal of Informetrics 6 (4): 674-88. https://doi.org/10.1016/j.joi.2012.07.001.

Gunnarsson, Evy. 2009. “"I Think I Have Had a Good Life”: The Everyday Lives of Older Women and Men from a Lifecourse Perspective." Ageing \& Society 29 (1): 33-48. https://doi.org/10.1017/S0144686X08007642.

Hildon, Zoe, Scott M. Montgomery, David Blane, Richard D. Wiggins, and Gopalakrishnan Netuveli. 2010. "Examining Resilience of Quality of Life in the Face of Health-Related and Psychosocial Adversity at Older Ages: What Is 'Right' About the Way We Age?" Gerontologist 50 (1): 36-47. https://doi.org/10.1093/geront/gnp067.

Hassing, Linda B., Scott M. Hofer, Sven E. Nilsson, Stig Berg, Nancy L. Pedersen, Gerald McClearn, and Boo Johansson. 2004. "Comorbid Type 2 Diabetes Mellitus and Hypertension Exacerbates Cognitive Decline: Evidence from a Longitudinal Study." Age and Ageing 33 (4): 355-61. https://doi.org/10.1093/ageing/afh100.

Hutnik, Nimmi, Pam Smith, and Tina Koch. 2012. "What Does It Feel like to Be 100? SocioEmotional Aspects of Well-Being in the Stories of 16 Centenarians Living in the United Kingdom." Aging \& Mental Health 16 (7): 811-18. https://doi.org/10.1080/13607863.2012.684663.

Janssen, Bienke M., Tineke A. Abma, and Tine Van Regenmortel. 2012. "Maintaining Mastery despite Age Related Losses. The Resilience Narratives of Two Older Women in Need of Long-Term Community Care." Journal of Aging Studies, Special Section: Innovative Approaches to International Comparisons, $26 \quad$ (3): 343-54. https://doi.org/10.1016/j.jaging.2012.03.003.

Jeon, Hae-Sook, and Ruth E. Dunkle. 2009. "Stress and Depression among the Oldest-Old: A Longitudinal Analysis." Research on Aging 31 (6): 661-87. https://doi.org/10.1177/0164027509343541.

Jopp, Daniela, Christoph Rott, and Frank Oswald. 2008. "Valuation of Life in Old and Very Old Age: The Role of Sociodemographic, Social, and Health Resources for Positive Adaptation." Gerontologist 48 (5): 646-58. https://doi.org/10.1093/geront/48.5.646. 
Klenk, Jochen, Clemens Becker, and Kilian Rapp. 2010. "Heat-Related Mortality in Residents of Nursing Homes." Age and Ageing 39 (2): 245-52. https://doi.org/10.1093/ageing/afp248.

Kleinspehn-Ammerlahn, Anna, Dana Kotter-Grühn and Jacqui Smith. 2008 "Self Perceptions of Aging: Do Subjective Age and Satisfaction with Aging Change During Old Age?" The Journals of Gerontology: Series $B \quad 63 \quad$ (6): 377-85. https://doi.org/10.1093/geronb/63.6.P377.

Komp, Kathrin. 2011. "The Political Economy of the Third Age." In Gerontology in the Era of the Third Age, edited by Dawn Carr and Katherin Komp, 51-66. New York: Springer.

Korhonen, Niina, Seppo Niemi, Mika Palvanen, Jari Parkkari, Harri Sievänen, and Pekka Kannus. 2012. "Declining Age-Adjusted Incidence of Fall-Induced Injuries among Elderly Finns." Age and Ageing 41 (1): 75-79. https://doi.org/10.1093/ageing/afr137.

Krause, Neal. 2004. "Lifetime Trauma, Emotional Support, and Life Satisfaction among Older Adults." The Gerontologist 44 (5): 615-23. https://doi.org/44/5/615 [pii].

Kydd, Angela, Anne Fleming, Sue Gardner, and Patricia Hafford-Letchfield. 2018. "Ageism in the Third Age." In Contemporary Perspectives on Ageism, edited by Liat Ayalon and Clemens Tesch-Roemer, 115-30. New York: Springer Open Press. https://link.springer.com/content/pdf/10.1007\%2F978-3-319-73820-8.pdf.

Lang, Frieder R., Paul B. Baltes, and Gert G. Wagner. 2007. "Desired Lifetime and End-of-Life Desires across Adulthood from 20 to 90: A Dual-Source Information Model." Journals of Gerontology. Series B, Psychological Sciences and Social Sciences 62 (5): 268-76. https://doi.org/10.1093/geronb/62.5.p268.

Larsson, Kristina. 2006. "Care Needs and Home-Help Services for Older People in Sweden: Does Improved Functioning Account for the Reduction in Public Care?" Ageing \& Society 26 (3): 413-29. https://doi.org/10.1017/S0144686X05004496.

Laslett, Peter. 1994. "The Third Age, the Fourth Age and the Future." Ageing \& Society. 14 (3): 436-47. Htps://doi.org/10.1017/S0144686X00001677.

Lee, Injeong, and Ruth E. Dunkle. 2010. "Worries, Psychosocial Resources, and Depressive Symptoms among the South Korean Oldest Old." Aging \& Mental Health 14 (1): 57-66. https://doi.org/10.1080/13607860903420997.

Liang, Kun. 2014. "The Cross-Domain Correlates of Subjective Age in Chinese Oldest-Old." Aging \& Mental Health 18 (2): 217-24. https://doi.org/10.1080/13607863.2013.823377.

Lloyd, Liz, Michael Calnan, Ailsa Cameron, Jane Seymour, and Randall Smith. 2014. "Identity in the Fourth Age: Perseverance, Adaptation and Maintaining Dignity." Ageing \& Society 34 (1): 1-19. https://doi.org/10.1017/S0144686X12000761.

Lowsky, David J., S. Jay Olshansky, Jay Bhattacharya, and Dana P. Goldman. 2014. "Heterogeneity in Healthy Aging." The Journals of Gerontology Series A: Biological Sciences and Medical Sciences 69 (6): 640-49. https://doi.org/10.1093/gerona/glt162.

MacDonald, Maurice, Peter Martin, Jennifer Margrett, and Leonard W. Poon. 2009. "Correspondence of Perceptions about Centenarians" Mental Health." Aging \& Mental Health 13 (6): 827-37. https://doi.org/10.1080/13607860902918249.

Mast, Benjamin T., A. R. Azar, and S. A. Murrell. 2005. "The Vascular Depression Hypothesis: The Influence of Age on the Relationship between Cerebrovascular Risk Factors and Depressive Symptoms in Community Dwelling Elders." Aging \& Mental Health 9 (2): 146-52. https://doi.org/10.1080/13607860412331336832.

McGinnis, Debra. 2009. "Text Comprehension Products and Processes in Young, Young-Old, and Old-Old Adults." Journals of Gerontology. Series B, Psychological Sciences and Social Sciences 64 (2): 202-11. https://doi.org/10.1093/geronb/gbp005.

Mitnitski, Arnold, Susan E. Howlett, and Kenneth Rockwood. 2017. "Heterogeneity of Human Aging and Its Assessment.” Journals of Gerontology: Series A 72 (7): 877-84. https://doi.org/10.1093/gerona/glw089. 
Moe, Aud, Ove Hellzen, Knut Ekker, and Ingela Enmarker. 2013. "Inner Strength in Relation to Perceived Physical and Mental Health among the Oldest Old People with Chronic Illness." Aging \& Mental Health $17 \quad$ (2): 189-96. https://doi.org/10.1080/13607863.2012.717257.

Momtaz, Yadollah A., Rahimah Ibrahim, Tengku A. Hamid, and Nurizan Yahaya. 2011. "Sociodemographic Predictors of Elderly"s Psychological Well-Being in Malaysia." Aging \& Mental Health 15 (4): 437-45. https://doi.org/10.1080/13607863.2010.536141.

Muramatsu, Naoko, and Hiroko Akiyama. 2011. "Japan: Super-Aging Society Preparing for the Future." The Gerontologist 51 (4): 425-32. https://doi.org/10.1093/geront/gnr067.

Ness, Jose, Dominic J. Cirillo, David R. Weir, Nicole L. Nisly, and Robert B. Wallace. 2005. "Use of Complementary Medicine in Older Americans: Results from the Health and Retirement Study." Gerontologist $45 \quad$ (4): 516-24. https://doi.org/10.1093/geront/45.4.516.

Neugarten, Bernice L. 1974. "Age Groups in American Society and the Rise of the Young-Old Bernice L. Neugarten, 1974." ANNALS of the American Academy of Political and Social Science 415 (1): 187-98. https://doi.org/10.1177/000271627441500114.

North, Michel S. and Susan T. Fiske. 2013. "Subtyping Ageism: Policy Issues in Succession and Consumption." Social Issues and Policy Review 7 (1): 36-57. https://doi.org/10.1111/j.1751-2409.2012.01042.x.

Oswald, Frank, Daniela S. Jopp, Christoph Rott, and Hans-Werner Wahl. 2011. "Is Aging in Place a Resource for or Risk to Life Satisfaction?" Gerontologist 51 (2): 238-50. https://doi.org/10.1093/geront/gnq096.

Ouchi, Yasuyoshi, Hiromi Rakugi, Hidenori Arai, Masahiro Akishita, Hideki Ito, Kenji Toba, Ichiro Kai, and Joint Committee of Japan Gerontological Society (JGLS) and Japan Geriatrics Society (JGS) on the Definition and Classification of the Elderly. 2017. "Redefining the Elderly as Aged 75 Years and Older: Proposal from the Joint Committee of Japan Gerontological Society and the Japan Geriatrics Society." Geriatrics and Gerontology International $17 \quad$ (7): 1045-47. https://doi.org/10.1111/ggi.13118.

Quéniart, Anne, and Michèle Charpentier. 2012. "Older Women and Their Representations of Old Age: A Qualitative Analysis.” Ageing \& Society 32 (6): 983-1007. https://doi.org/10.1017/S0144686X1100078X.

Roth, Erin G., Lynn Keimig, Robert L. Rubinstein, Leslie Morgan, J. Kevin Eckert, Susan Goldman, and Amanda D. Peeples. 2012. "Baby Boomers in an Active Adult Retirement Community: Comity Interrupted." Gerontologist 52 (2): 189-98. https://doi.org/10.1093/geront/gnr155.

Sabharwal, Sanjeeve, Helen Wilson, Peter Riley and Chinmay Gupte. "Heterogenity of the definition of elderly age in current orthopaedic research." Springer Plus Open Journal 4 (516). https://doi.org/10.1186/s40064-015-1307-x.

Serra, Valentina, John Watson, David Sinclair and Dylan Kneale. 2011. Living Beyond 100: A Report on Centenarians. London: International Longevity Centre. https://ilcuk.org.uk/wp-content/uploads/2019/03/Living-Beyond-100-A-report-oncentenarians.pdf.

Thygesen, Elin, Hans I. Saevareid, Torill C. Lindstrom, and Knut Engedal. 2009. "Psychological Distress and Its Correlates in Older Care-Dependent Persons Living at Home." Aging \& Mental Health 13 (3): 319-27. https://doi.org/10.1080/13607860802534591.

United Nations. 2015. "World Population Prospects The 2015 Revision, Key Findings and Advance Tables." Working Paper ESA/P/WP.241. New York: United Nations, Department of Economic and Social Affairs, Population Division.

Wastesson, Jonas W., Marti G. Parker, Johan Fastbom, Mats Thorslund, and Kristina Johnell. 2012. "Drug Use in Centenarians Compared with Nonagenarians and Octogenarians in 
Sweden: A Nationwide Register-Based Study." Age and Ageing 41 (2): 218-24. https://doi.org/10.1093/ageing/afr144.

Weyerer, Siegfried, Sandra Eifflaender-Gorfer, Birgitt Wiese, Melanie Luppa, Michael Pentzek, Horst Bickel, Cadja Bachmann, Martin Scherer, Wolfgang Maier, and Steffi G. RiedelHeller. 2013. "Incidence and Predictors of Depression in Non-Demented Primary Care Attenders Aged 75 Years and Older: Results from a 3-year Follow-up Study." Age and Ageing 42 (2): 173-80. https://doi.org/10.1093/ageing/afs 184.

Windsor, Tim D., Richard A. Burns, and Julie E. Byles. 2013. "Age, Physical Functioning, and Affect in Midlife and Older Adulthood." Journals of Gerontology. Series B, Psychological Sciences and Social Sciences $68 \quad$ (3): 395-99. https://doi.org/10.1093/geronb/gbs088.

Wodak, Ruth, Barbara Johnstone, and Paul E Kerswill. 2011. The SAGE Handbook of Sociolinguistics. London: SAGE Publications.

Woods, Robert T. 1996. Handbook of the Clinical Psychology of Ageing. Chichester: John Wiley and Sons.

World Health Organization. 2015. World Report on Ageing and Health. Geneva: World Health Organization.

World Health Organization Health Assembly. 2017. The Global Strategy and Action Plan on Ageing and Health 2016-2020: Towards a World in Which Everyone Can Live a Long and Healthy Life. World Health Organization. http://www.who.int/ageing/globalstrategy/en/.

Xie, Jing, Fiona E. Matthews, Carol Jagger, John Bond, and Carol Brayne. 2008. "The Oldest Old in England and Wales: A Descriptive Analysis Based on the MRC Cognitive Function and Ageing Study." Age and Ageing 37 (4): 396-402. https://doi.org/10.1093/ageing/afn061.

Yashin, Anatoliy I., Konstantin G. Arbeev, Liubov S. Arbeeva, Deqing Wu, Igor Akushevich, Mikhail Kovtun, Arseniy Yashkin, et al. 2016. "How the Effects of Aging and Stresses of Life Are Integrated in Mortality Rates: Insights for Genetic Studies of Human Health and Longevity." Biogerontology 17 (1): 89-107. https://doi.org/10.1007/s10522-0159594-8

Zimmer, Zachary. 2005. "Health and Living Arrangement Transitions among China"s OldestOld.” Research on Aging 27 (5): 526-55. https://doi.org/10.1177/0164027505277848.

Zimmermann, Harm-Peer, and Heinrich Grebe. 2014. "'Senior Coolness': Living Well as an Attitude in Later Life." Journal of Aging Studies 28 (1): 22-34. https://doi.org/10.1016/j.jaging.2013.11.002.

\section{ABOUT THE AUTHORS}

Dr. Angela Kydd: Professor of Clinical Nursing, Robert Gordon University and NHS Grampian, Aberdeen, Scotland, UK

Dr. Anne Fleming: Independent Researcher, Bishopbriggs, Glasgow, Scotland, UK

Dr. Isabella Paoletti: Senior Researcher, Social Research and Innovation Centre (CRIS), Perugia, Italy

Dr. Simona Hvalič-Touzery: Assistant Professor, Faculty of Social Sciences, University of Ljubljana, Ljubljana, Slovenia 
The Journal of Aging and Social Change is an international journal for aging research. It features articles on the dynamic interplay between aging and society, exploring advances in social and behavioral science on aging, life-course and social change, involving (but not limited to) gerontology, sociology, demography, psychology, economics, communication science, education, epidemiology, public health, biology, nursing and medicine. The Journal of Aging and Social Change is devoted to multi- and interdisciplinary research that centers around social and behavioral science as well as to disciplinary approaches that are compatible and advantageous beyond merely discipline-specific discourses.

Articles published in The Journal of Aging and Social Change focus on theoretical, conceptual and/or methodological advances, on the growth of empirical knowledge about age and aging in an increasingly diverse and changing global society, as well as on the impact and relevance of knowledge about aging for policies and the global society. Besides original empirical research articles, The Journal of Aging and Social Change includes brief research reports, articles that focus on theoretical and methodological advances, and review articles on cutting-edge topics. All submissions are peer-reviewed, supported by rigorous processes of criterion-referenced article ranking and qualitative commentary, to ensure the substance and significance of the published works. 